\title{
Volkswagen Blues: Rebirth through communication
}

\begin{abstract}
Andrea Portt
The following manuscript was originally prepared for FREN*3200 Quebec Novel, and later translated from the original French under the supervision of Professor Stéphanie Nutting, French Studies, School of Languages and Literatures, College of Arts.

Jacques Poulin's novel Volkswagen Blues traces the author Jack Waterman's journey of self-discovery from Jacques Cartier's landing point in Gaspé, south down the voyageurs' route via the St. Lawrence and the Mississippi, and finally west along the pioneers' Oregon Trail to San Francisco. Throughout the trip, Jack encounters figures from the many different cultural backgrounds and periods that were important in the creation of today's multicultural and plurilingual North America. The narrator uses a mixture of languages throughout the novel to emphasize these different cultures and eras, and to call attention to the importance of language to human existence and society. Jack finds selfreconciliation by accepting his connection to others through contact with these other cultures and languages.
\end{abstract}

$\mathrm{N}$ orth American history was built by waves of immigration, first over the Bering Strait from Asia, and later from Europe across the Atlantic Ocean. Europeans first arrived in search of a route to Asia, and later came in hopes of finding freedom and prosperity. Jacques Poulin's novel Volkswagen Blues could be seen as a chronicle of these immigrants' lost dreams. The narrator describes the lives of explorers and voyageurs who failed to find Eldorado, and depicts the pioneers as ordinary people who never reached the Promised Land. He goes on to tell the story of the massacres of the native North American population. Nevertheless, this novel is more than a story of broken dreams. As the protagonists, Jack and La Grande Sauterelle follow the paths of early Europeans across North America, they piece together a personal understanding of their identities through clues found in narratives of collective history. They discuss the past with a Native American, Canadians, and Americans, thereby discovering a history where cultures have combined to create the complex fabric of today's North America. By the end of the novel Jack has found new inspiration to continue his writing, and La Grande Sauterelle decides to "spend a while in San Francisco: she thought that city, where the races seemed to live in harmony, was a good place to try to come to terms with her own twofold heritage, to become reconciled with herself". ${ }^{1}$ Throughout the novel, the protagonists gain an understanding of themselves by piecing together the mixed cultural history of North America. The narrator uses language as one of the strongest indications of culture. Both the original French version and the English translation of Volkswagen Blues are plurilinguistic novels; several languages slip through the pages and across chapters. The narrator employs these different languages in order to illustrate the blended reality of
North America as well as the interdependence of languages, cultures, and individual existence.

France Bernier points out that "Dans Volkswagen Blues, [...] l'Amérique française et l'Amérique actuelle se croisent

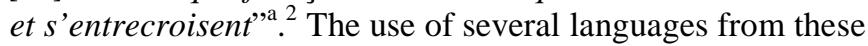
periods in the novel reinforces the impression of pluriculturalism over time on this continent. Before his disappearance, Jack's long-lost older brother Théo copied a passage written by the French explorer Jacques Cartier onto a postcard, which he sent to Jack. Théo even went so far as to reproduce exactly the sixteenth century handwriting and spelling, as shown in the illustration in the first chapter. He transcribed Cartier's archaic orthography "nous mismes tous à genoulz, les mains joinctes",3 instead of using today's spelling "nous mîmes tous à genou, les mains jointes" to describe the Europeans' prayers "we all knelt down with our hands joined". 4 A reproduction of Cartier's original writing can be seen in La grande aventure de Jacques Cartier: épave bi-centenaire découverte au Cap des Rosiers en 1908, available in pdf format from the website of the Bibliothèque et Archives nationales du Québec. ${ }^{5}$ This choice of faithfully transcribing the handwriting and spelling embeds Théo's identity in an era that ended long before his birth.

Later in the narrative, Jack and La Grande Sauterelle meet unilingual Americans, such as the bull rider's wife, who had met Théo years ago as he traveled toward San Francisco. Jack has trouble communicating in English. Even so, the original novel includes Jack's linguistic struggles in English instead of French as he stumbles over the pronunciation of "recognized," which is a word that he considers quite terrible $e^{b}$. The narrator also chooses to include the English of the American signs "Soft shoulder"7 and "On the terrace". 8 Leaving these discussions and signs untranslated increases 
the believability of the novel by reminding the reader of the predominantly Anglophone nature of today's America. As well as underscoring the realism of the novel, the inclusion of other languages "suppose une compétence de lecteur bilingue" ${ }^{\text {"c }}$ according to Simon, ${ }^{9}$ and suggests a greater theme: the affect of language on individuals and culture.

In the seventh chapter, the narrator describes graffiti inside the old Volks: "a mysterious inscription in German, under the sun visor on the driver's side, read[s]: Die Sprache ist das Haus des Seins.". ${ }^{10}$ This is a quote attributed to the German philosopher Heidegger and translates to "Language is the home of being." Or, as Bernier explains: "En d'autres mots, l'homme trouve sa vérité [...] par le langage, fondation de l'être"d.11 David Cerborne explains that "in [Heidegger's] later philosophy, the notion of a being who has an understanding of being, who can stand in a relation to being (both of beings and as such), and yet lacks language is a non-starter". ${ }^{12}$ This is to say that language is essential for a person to understand themself and the surrounding world. Language holds significance throughout Jack and La Grande Sauterelle's journey of self-discovery. The idea of existence based in language is emphasized by the main characters' explorations in English, which is their second language. Their mastery of English reflects their levels of understanding of other areas of life.

To take Jack as an example, "[h]e didn't like himself very much in general". ${ }^{13} \mathrm{He}$ finds himself too withdrawn and "what he hated about himself more than anything was his way of working". ${ }^{14}$ Moreover, Jack admits that he has never loved anyone, and that for him expressing oneself through writing is "a way of not living". 15 As the author of five novels published in Quebec, Jack has definitely proven his mastery of his first language, French. In spite of this, he struggles in English. Jack hesitates when the American customs officer asks him about his travel plans. This of course raises suspicion with the officer, who sends him to the Immigration Service for further questioning " $[b]$ ecause [he doesn't] seem to know anything". ${ }^{16}$ Furthermore, he stumbles while talking to the bull rider's wife, and must defer to La Grande Sauterelle to carry the conversation. These difficulties in his second language reflect the general feeling of detachment and confusion from which Jack suffers. Indeed, he admits to going around with his "head full of a sort of permanent fog" ${ }^{\prime 17}$ and to lacking confidence. Luckily for Jack, he meets La Grande Sauterelle; through her he learns "à mieux se défendre dans la vie"" 18

Like Jack, La Grande Sauterelle has a great passion for the written word, but admits that she too would generally rather be alone. Nevertheless, they set off together in search of their own roots and identities. Although they are struggling with their respective identities, La Grande Sauterelle is more self-assured than Jack. This makes her capable of helping him in his search for his brother Théo. She is able to fix the old Volks with her skills in mechanics, and has an unerring sense of direction that keeps them from getting lost, as well as having "une connaissance intuitive des gens et de leurs actes" ${ }^{19}$ Jack wonders how she manages " to have such clear ideas" ${ }^{20}$ with which she explains Théo's motives and actions as he traveled across North America ahead of them.

Language is another tool that La Grande Sauterelle employs during their quest. She has a better grasp of the English language than Jack. As a result, she is able to ask the bull rider's wife important questions "with her amazing accent"21 (when Jack doesn't "seem to know what to say") 22, thereby continuing the search for Théo. Her mastery of English mirrors her capabilities in other walks of life and helps her and Jack discover that they have to accept "de vivre au contact de l'autre" in order to understand their identities. ${ }^{23}$ This is to say that they don't just need one another, but they also need other languages and cultures in order to put together the clues that Théo left behind, reach their destination, and eventually gain self-comprehension and reconciliation.

La Grande Sauterelle also represents pluriculturalism. Her mother is Montagnaise, and her father is French Canadian. The narration alternates between her two names, La Grande Sauterelle and Pitsémine, not simply to reflect her mixed heritage, but also to emphasize her role as a guide. "Pitsémine est le mot montagnais utilisé pour désigner la sauterelle [...] Il peut également être utilisé dans le sens de «pousser»", ${ }^{24}$ The narrator used this Native American word as the root of her French name La Grande Sauterelle - Tall Grasshopper - and to highlight her guiding role. She literally and figuratively pushes Jack to have the confidence required to find his brother. When Jack grew too hesitant to talk to Mr. Ferlinghetti at the City Lights bookstore, "the girl gave him a firm push in the back" to force him into the store. ${ }^{25}$ She also encourages him by pretending to be a "great psychologist". ${ }^{26}$ After Jack hears his brother's childhood idol Étienne Brûlé described as a "bum," and learns that his brother was arrested years ago in Kansas, he falls into an acute depression that he refers to as his deep-sea diver's complex. He is greatly disturbed by his sudden loss of faith in these two figures that he had worshipped since childhood. La Grande Sauterelle aids his recovery by forcing him to consider the pressure of his real emotions with regard to Étienne Brûlé and Théo, and with her help, is eventually able to come to terms with the deconstruction of his childhood heroes into mere men.

At the end of their journey, Jack and La Grande Sauterelle finally find Théo in San Francisco. Even though he is taken aback when he finds his brother afflicted by amnesia and creeping paralysis, Jack finally has the inspiration to devote himself to writing a new novel. Although he has suffered a loss of faith in his childhood heroes, and has been re-united with a brother who is terminally ill and unable to recognize him, Jack has been reborn through his journey. In conversation with La Grande Sauterelle and others across North America, Jack has learned 
to accept contact with her and the outside world, and has acquired a deeper sense of self. The fact that a young Métis woman plays such an important role in Jack's transformation and his search for family and identity underlines the theme of cultural interdependence. The author employed sixteenth century French and modern English to make the novel more representative of historic and current North America, while at the same time blending Théo's identity with the past. Philosophical German graffiti and the protagonists' use of written language and spoken English illustrate the importance of language to human existence. La Grande Sauterelle's heritage and names hint at the importance of positive intercultural relations in the pluricultural landscape of North America. The novel finishes with the image of Jack, content with a fresh view of himself and his homeland "smiling in spite of everything at the thought that somewhere in the vastness of America, there was a secret place where the gods of the Indians and the other gods were meeting together in order to watch over him and light his way". ${ }^{27}$

\section{ENDNOTES}

1. Poulin, Jacques, (1984) (2004), Volkswagen Blues, translated by Sheila Fischman, Toronto, Cormorant Books, 219-220.

2. Bernier, France, (1998), Du paratexte au texte: lire l'Amérique dans Volkswagen Blues de Jacques Poulin, Laval, Faculté des Lettres Université Laval, 72.

3. Poulin, Jacques, (1984) (1998), Volkswagen Blues, Montréal, Babel, 18.

4. Poulin, translated by Fischman, 9.

5. Pouliot, J. Camille, (1934), La grande aventure de Jacques Cartier : épave bi-centenaire découverte au Cap des Rosiers en 1908, Paris, H. Michelant et A. Ramé, 42.

6. Poulin, 211.

7. Poulin, 108.

8. Poulin, 113.

9. Simon, Sherry (1994), Le trafic des langues : traduction et culture dans la littérature québécoise, Montréal, Boréal, 172. 10. Poulin, 92.

11. Bernier, 26.

12.Cerborne, David R., (2008), Heidegger : A Guide for the Perplexed, London, Continuum, 64.

13. Poulin, translated by Fischman, 31 .

14. Poulin, translated by Fischman, 31 .

15. Poulin, translated by Fischman, 98 .

16. Poulin, translated by Fischman, 64 .

17. Poulin, translated by Fischman, 11 .

18. Lintvelt, Jaap, (2000), Aspects de la narration : thématique, idéologie et identité : Guy de Maupassant, Julien Green, Anne Hébert, Jacques Poulin, Québec, Éditions Nota bene, 218.

19. Bernier, 78.

20. Poulin, translated by Fischman, 11 .
21. Poulin, translated by Fischman, 141.

22. Poulin, translated by Fischman, 144.

23. Boivin, Aurélien, (1996), Pour une lecture du roman québécois : de Maria Chapdelaine à Volkswagen blues, Québec, Nuit blanche, 355.

24. Bernier, 77.

25. Poulin, translated by Fischman, 204.

26. Poulin, translated by Fischman, 53 .

27. Poulin, translated by Fischman, 221-222.

\section{Acknowledgements}

Special thanks to Dr. Stéphanie Nutting for her passionate lectures and discussions on Francophone culture in North America, as well as for her support and supervision of this paper. Dr. Margot Irvine's careful editing of this manuscript is greatly appreciated; many thanks are also due to Carmen Evans for encouragement and to Professor Waldemar Scholtes for help translating the Old Volks' graffiti.

\section{REFERENCES}

Bernier, France, (1998), Du paratexte au texte: lire l'Amérique dans Volkswagen Blues de Jacques Poulin, Laval, Faculté des Lettres Université Laval.

Cerborne, David R., (2008), Heidegger: A Guide for the Perplexed, London, Continuum.

Lintvelt, Jaap, (2000), Aspects de la narration : thématique, idéologie et identité : Guy de Maupassant, Julien Green, Anne Hébert, Jacques Poulin, Québec, Éditions Nota bene.

Poulin, Jacques, (1984) (1998), Volkswagen Blues, Montréal, Babel.

Poulin, Jacques, (1984) (2004), Volkswagen Blues, translated by Sheila Fischman, Toronto, Cormorant Books.

Pouliot, J. Camille, (1934), La grande aventure de Jacques Cartier : épave bi-centenaire découverte au Cap des Rosiers en 1908, Paris, H. Michelant et A.Ramé.

Simon, Sherry (1994), Le trafic des langues : traduction et culture dans la littérature québécoise, Montréal, Boréal.

\section{FoOTNOTES}

a "In Volkswagen Blues, [...] New France and contemporary North America cross and intertwine with one another."

${ }^{\mathrm{b}}$ daunting

c "assumes a competently bilingual reader"

d "In other words, man finds his truth [...] through language, the foundation of being."

e "to stand up for himself better in life"

$f$ " [...] an intuitive understanding of people and their actions"

$\mathrm{g}$ "living in contact with the other"

$\mathrm{h}$ "Pitsémine is the Montagnais word for grasshopper [...] It can also be used to mean "to push"” 